University for Business and Technology in Kosovo

UBT Knowledge Center

UBT International Conference

2013 UBT International Conference

Nov 2nd, 11:45 AM - 12:00 PM

\title{
If there is a need to fix accounting and to transform companies?
}

\author{
Besnik Skenderi \\ University for Business and Technology, besnik_skenderi@yahoo.com \\ Diamanta Skenderi \\ Tax Administration of Kosovo, diamanta_skenderi@yahoo.com
}

Follow this and additional works at: https://knowledgecenter.ubt-uni.net/conference

Part of the Business Commons

\section{Recommended Citation}

Skenderi, Besnik and Skenderi, Diamanta, "If there is a need to fix accounting and to transform companies?" (2013). UBT International Conference. 38.

https://knowledgecenter.ubt-uni.net/conference/2013/all-events/38

This Event is brought to you for free and open access by the Publication and Journals at UBT Knowledge Center. It has been accepted for inclusion in UBT International Conference by an authorized administrator of UBT Knowledge Center. For more information, please contact knowledge.center@ubt-uni.net. 


\title{
If there is a need to fix accounting and to transform companies?
}

\author{
Besnik Skenderi ${ }^{1}$, Diamanta Skenderi² \\ University for Business and Technology, Information Systems,
}

Email: besnik_skenderi@yahoo.com

\begin{abstract}
This paper is about accounting system that is lectured to scholars and in a same is used by companies. In actual business environment companies are dealing with two stakeholders; government is interested to collect taxes and shareholders are interested to collect their profit and dividend. Moreover, current accounting system in place, most companies consider equity capital as a free resource. In this paper author had discussed about equity capital, pension accounts, EVA and employs role and decision making.
\end{abstract}

Keywor ds : Accounting, EVA, Equity Capital

\section{Problems with Accounting}

Because of company growths, international markets and rapid changes in the business environments, many businesses are outsourcing services, and their shareholders are employing companies and professionals to manage their accounting. While the best practices are in place in the field of project management, information technology and risk analysis, the accounting and corporate governance techniques and rules are outdated. Accountants and accounting companies are reporting to shareholders information's about profit and in the same time they are declaring taxes to the government. In this, situation companies are dealing with two stakeholders; government is interested to collect taxes and shareholders are interested to collect their profit and dividend. Many businesses and governments have faced in the past and are continuing to face many problems related to finances (e.g. Enron, WorldCom, Greece). In many cases managers are tricked to bring decision based on the reports which are produced by the accountants, while those reports are not providing all the necessary information's which can be used in the proper decision making process.

\section{Equity Capital}

According to the current accounting system in place, most companies consider equity capital as a free resource (Stewart, 2002), and they use this capital in order to finance new projects without placing any economic value on those funds. However, cost of equity is not a cash cost but it is an opportunity cost and accountants should be aware and they should be transparent regarding accounting profit and economic profit. For example in the company where I am employed, Post and Telecom of Kosovo, terminology such as economic profit, cost of capital and net present value are not considered during the process of investment evaluation. In elaborating cost of capital or applying EVA formula, using the simple example when initially considering projects, a project may seem that is providing return on investment per say 5\% it may look as if the company has reached sufficient profit. Nevertheless, assuming that instead of investing on this project, the company could invest the same amount of capital with minimum risk at the interest rate of $5 \%$ in a bank, it will be much more convenient to place those funds in a bank rather than investing in a project that yields the same interest plus higher risk. In theory, this concept may look as the appropriate one, but if companies are investing money in the banks with low risk than those companies will start to compete with each other in a market of "interest rate", and as a result, banks may decrease interest rate that are currently offering. Implementation of this concept may provide profit with low risk but in the long term it will have negative impact on gaining new markets, getting experience and there will not be any technology improvement and innovations. For example what would happen if Microsoft would only invest its capital in the bank? However, there are cases when companies are keeping cash in banks, for example in Kosovo Post and Telecom had kept 300 mil $€$ in the banks and when management had decided to withdraw money from the banks the entire 
bank system in country was destabilized and as a result bank had implement downsizing for their employees. Nevertheless, companies will have to invest their capital in their projects, but they have to make sure that the return they gain is higher than the opportunity cost of the same amount investing in a bank.

\section{Operating and Financing Decisions}

During the process of decision making regarding the sources for financing projects, sometimes, accounting is improperly as sociating financing sources with investment uses that means that companies are mixing operating and financing decisions. Regarding this issue (Stewart, 2002) states that "the root of the problem is that traditional accounting measures look very different depending on whether debt or equity finances a new investment" (p.5). Financing new investments with bank loans seems to be the preferred method of accountants since financial reports will show a "virtual" profit from those investments while in reality with this step the value of companies is decreasing. In order to s top this ongoing investment practice, accountants should separate operating and financing decisions and in a same time, they should change the reporting routine to managers in that way that managers will be properly informed about companies debt, profit, return on equity and earnings per share.

\section{Pension Accounts}

In the actual business environment, accountants are reporting to shareholders and to the government. While government is interested to collect taxes, shareholders are interested to gain the profit, but interested parties are also employees, since in many countries companies are also managing their employee's pension funds. The issue with accountants is that they are not considering those accounts as true corporate liabilities and assets. Companies should invest those in industries where the risk is low and they should not invest them where the risk is high because if company will lose those funds, the company will still need to pay back pensions to their employees. Government regulations regarding pension funds are different depending on which country the companies are operating. For example, in my country, Republic of Kosovo, companies and employees pay $5 \%$ of the salary in a pension fund known as a trust fund which funds are managed by the government.

\section{Innovation, Strategic Investments and Depreciation}

As there are, only two ways for companies to grow, through innovation and market growth, companies will have to place a significant amount of resources in innovating and bringing new products. Considering that around $90 \%$ of new products fail, companies need to be very careful when designing new products that will reach the market. In addition, nowadays companies are facing shorter product lifetime cycles, meaning that they have to make sure that the return on investments in product is faster than possible. Some products that may be in the "cash cow phase" may soon become "poor dogs".

Nowadays many successful companies have research and development departments and those departments in many cases are playing the role in triggering new products and services that are creating profit for the companies. It may take several years until those departments are making a profit, but the current accounting system that is in place is not showing those departments as an ass et on balance sheets. Some companies are also running in house training centers and some companies are outsourcing those services. In this way, companies are gaining competitive advantage and in a same time are increasing capacities of their staff. Again, issue is with the accountants since in the balance sheets those departments do not appearas the asset even that in practice they possess a high value. Despite missing information's for research and development, actual financial and accounting statements are not showing all the risk outlays and those accountants should find the way to declare thembecause they may prevent the future failure and in a same time they will reduce the profit loss. In time of globalization, companies are entering in the new markets with existing products and services, but it may take long time before offered products and services start to bring back the investment. For example if a car dealership 
company is starting to operate in new country, it will take 3 to 5 years to bring back the investments and that because in beginning the car dealership will need to sell many vehicles in order to create customers base which will bring the vehicles for the maintenance and repair. In this case, according to the accountants, the car dealership is operating with no profit and in some cas es it is creating loss but in reality, company is creating new customers and new market. Companies possess equipment and property which is presented in the balance sheets, but the issue remains on the declared value and depreciation method. In the accounting is used "straight line "depreciation which differs from the economic depreciation. For example, a company owns the equipment that was purchased for the price of 10 mil $€$. In the balance sheet that equipment will be declared as an asset and the value of that asset will be depreciated $10 \%$ per year, so after 10 years that equipment in balance sheet will have the value of $0 €$. However, in reality, that piece of equipment it will still be used or it can be sold as second hand equipment or as a scrap. Despite this traditional accounting is not showing the expense that company may have in order to remove the depreciated equipment because of environment protection laws.

\section{EVA (Economic Value Added)}

In order for companies to create value, they have to be able to yield profit that is greater than the costs of using those funds to creating the value, meaning that companies would have to fund their activities through own equity or debt, and using this amount there is a cost to it. In case that organization is not able to yield profit that overcomes that cost, organizations as such will not be attractive to potential investors. Discussion as such brings to the question the type of employed methodology in measuring organization activities. One of the methods that overcome old-fashioned financial systems is a methodology first used by Stern \& Stewart Co., a terminology known as Economic Value Added (EVA). Economic Value Added concept is providing more accurate information's that are used by decision makers compared to the traditional accounting reporting routine. With EVA ${ }^{\circledR}$ it is possible to see which the exact profit is after deducting taxes and cost of capital from net operating profit.

$$
\text { EVA }=\text { Net Operating Profit }- \text { Taxes }- \text { Cost of Capital }
$$

\section{Employees and decision making}

Nowadays companies are employing wide range of staff with different professional background, expertise and different culture. In order to be more competitive employees are investing on themselves in formal and in professional education and as a result lot of thempossess managerial, interpersonal and information technology skills. This diversity among employees can be used as a "capital" from companies in that way that employees can be involved in the decision making process. However, including employees in the decision, making process may be a challenging step and it may introduce resistance to change from managers because they will fear cultural change. Trade Unions can play important role during the trans formation of decision-making process and profit share among companies. Trade Unions may be part of the problem or may help in implementation of this process. In countries where the law is in place and legal system is functioning properly, trade unions should cooperate with management in order to create more profit and to improve business processes. Another factor which can jeopardize employee involvement in the decision making process is cultural difference between employees especially in international companies. Considering the increase number of service economy, companies should think more of employee empowerment, meaning the inclusion of employees at the operational level of decision making. Since this line of discussion includes front line staff, it is necessary for companies to make sure that the best customer facing people are representing the company. The best way for companies to include their employees in the decision making of companies is by flattening organizational structures, enabling each personnel think as entrepreneur without losing the pers pective of the customer. Including employees in decision, making process will serve also as the motivating factor, since when employees are motivated their performance will be better. In this way, a partnership will be created between shareholders, managers and employees and this partnership will function in decision-making process and in profit share. Employees will be eligible for bonus payments based on their performance but they will also share the risk with shareholders. 


\section{References}

1 Foss, N. J. (2001). Miseian Ownershp and Coasin Authority in Hayekian Settings: The Case of the Knowledge Economy. The Quarterly Journal of Australian Economcs, 4(4), 3-23.

2 Schonburg, J., \& Stern, E. (1999, June). The Capitalist Manifesto The Transformation of the Corporation -Employee Captalism-. EVAluation, 1(4), pp. 1-17.

3 Stewart, G. B. (2002, September). Accounting Is Broken Here's How to Fix t A Radical Manifesto. Stern Stewart, 5(1), pp. 1-29. 